\title{
ABSENCE FROM WORK IN RELATION TO WAGE LEVEL AND FAMILY RESPONSIBILITY
}

\author{
BY \\ R. D. SHEPHERD and J. WALKER \\ From the Medical Research Council's Industrial Psychology Research Group at University College, London
}

(RECEIVED FOR PUBLICATION JUNE 15, 1957)

This paper discusses the relation between absence from work and wage level and absence and the number of dependants. The extent of overtime working is also considered. The investigation was made in a large iron and steel works.

\section{Description of Firm}

The plant is modern and the various processes of preparing the iron ores through to steel rolling are highly mechanized. There is a considerable diversity of occupations and physical conditions of work with few men employed on any one operation. Owing to the processes involved most production men are on continuous three-shift work, the plant being manned 24 hours a day throughout the year. The remainder of the men are mainly on discontinuous three-shift systems, work stopping over the whole or part of the weekend.

The majority of jobs in a section are arranged in promotion grades with corresponding differences in basic pay. In addition to the basic rate, men on production work receive a bonus dependent upon the output of their own or an associated section. Since the productivity of a department is largely determined by the capacity of the plant, skilful maintenance, and the supply of materials, this bonus is often relatively remote from individual effort and may be considered as part of a fixed wage. As well as the various wage levels within a department there are also differences in wage level between departments which have developed over the years. Thus jobs at the same wage level do not necessarily require the same skill and responsibility.

Other factors relevant to the study are the existence of a comprehensive medical service with two fulltime medical officers and a staff of qualified nurses, and an employees' benevolent scheme which provides just over $£ 1$ per week after 14 days' sickness absence. There was a labour shortage in the works during the period studied. The absence rate was about $4 \%$ at which level the management did not consider absence to be a problem.

\section{Sources of Data and Sampling Methods}

The firm's individual absence records were compiled from clock cards and foremen's lists. The record distinguished between certified and uncertified sickness absence, absences with and without permission, and those due to injury. In many cases, however, it was difficult to establish the cause of absence and any classification must be treated with caution. The personnel cards were arranged by department and occupation and from these every fourth man was selected; in addition, data were extracted for men on the main production jobs, in all, approximately 1,000 men. For each man a note was made of his occupation, age, income tax code number, length of service, basic and bonus rate, annual gross earnings, absence during 1951-52, and number of hours paid. No cumulative record of actual hours worked, or of overtime, was kept. It was possible, however, to estimate the number of overtime hours paid for each man for a nine months' period.

Some indication of the physical demands and conditions of work-heaviness, temperature, continuity of working, etc. - was obtained from ratings by foremen and managers. Heaviness was rated from 1 for very heavy work to 7 for very light work, and temperature of the work situation as 1,2 , and 3 for hot conditions, some heat, and normal respectively. For further discussion of the procedure see Shepherd and Walker (1957). Ratings on most jobs were made by more than one person and the agreement between judges was found to be high.

\section{Method of Analysis}

For present purposes only those men on production jobs, on three-shift work ( 21 and 19 shift cycles), and employed throughout 1952 have been included. 
They were from several departments but had similar hours of work which averaged 48 per week throughout all but a short part of the period.

The men were divided into six groups according to their hourly wage rate throughout 1952 . This rate is independent of absence and overtime working and represents the pay associated with attendance during normal working hours. The pay intervals were arranged to provide approximately equal numbers in the groups, which were then divided into five on the basis of the income tax code number; these subgroups represented men with different numbers of dependants.* At this stage it was found necessary to exclude all men with no dependants owing to their small numbers in the higher pay groups. Men in the six wage groups were then matched as nearly as possible for income tax code number, age, heaviness of work, and temperature. Although this procedure reduced the number of men available from approximately 600 to 245 , it was necessary in order to control important variables other than those under consideration. Table 1 shows that the wage groups were well matched for number of dependants and were reasonably comparable for age, heaviness of work, and temperature. The wage rate of the highest paid group was nearly double that of the lowest; when the average annual gross earnings were examined the difference in

* The income tax code number has been used to give some indication of a man's family responsibilities. For further discussion see later. earnings between the extreme wage groups was about $£ 300$.

\section{Results}

Absence and Wage Level.-Table 2 shows the total absence and the absence within each category for the six wage groups in terms of the number of absences and shifts lost. The figures given are rates which express the amount of absence per 100 men per year. Absences recorded as due to sickness but for which no certificate was brought were few and have been grouped with the certified sickness. The number of absences due to injury was very small and the figures are given only for the three lower and upper pay groups combined.

The total absence figures show that, apart from the lowest paid group, both the average number of absences and shifts lost increase as rate of pay increases. The relatively high absence of the lowest paid group is due mainly to more absences without permission and more longer absences with permission. In general absence without permission varies with wage level, although the association appears to break down in the highest and lowest wage groups. For absence with permission there is little relationship although, taken together, there is slightly more in the three lower pay groups. For sickness absence, however, there is an increase, both in shifts lost and number of absences, with increasing wage level.

TABLE 1

NUMBER OF MEN AT EACH WAGE LEVEL AND DISTRIBUTION BY INCOME TAX CODE NUMBER, AVERAGE AGE, AND AVERAGE RATING OF PHYSICAL CONDITIONS OF WORK

\begin{tabular}{|c|c|c|c|c|c|c|c|c|}
\hline \multirow{2}{*}{$\begin{array}{c}\text { Hourly Rate } \\
\text { (shillings) }\end{array}$} & \multicolumn{4}{|c|}{$\begin{array}{l}\text { No. of Men in each Income Tax } \\
\text { Code Number Group }\end{array}$} & \multirow{2}{*}{$\begin{array}{l}\text { Total No. } \\
\text { of Men }\end{array}$} & \multirow{2}{*}{ Average Age } & \multirow{2}{*}{$\begin{array}{c}\text { Average } \\
\text { Heaviness } \\
\text { Rating }\end{array}$} & \multirow{2}{*}{$\begin{array}{c}\text { Average } \\
\text { Temperature } \\
\text { Rating }\end{array}$} \\
\hline & $50-89$ & $90-109$ & $110-124$ & Over 124 & & & & \\
\hline $\begin{array}{l}3 \cdot 4-4 \cdot 09 \\
4 \cdot 1-4 \cdot 29 \\
4 \cdot 3-4 \cdot 49 \\
4 \cdot 5-4 \cdot 89 \\
4 \cdot 9-5 \cdot 99 \\
6 \cdot 0 \text { and over }\end{array}$ & $\begin{array}{r}9 \\
12 \\
12 \\
9 \\
10 \\
9\end{array}$ & $\begin{array}{r}8 \\
12 \\
12 \\
10 \\
10 \\
9\end{array}$ & $\begin{array}{r}99 \\
12 \\
12 \\
10 \\
10 \\
9\end{array}$ & $\begin{array}{r}9 \\
12 \\
12 \\
9 \\
10 \\
9\end{array}$ & $\begin{array}{l}35 \\
48 \\
48 \\
38 \\
40 \\
36\end{array}$ & $\begin{array}{l}43 \\
42 \\
42 \\
43 \\
40 \\
42\end{array}$ & $\begin{array}{l}4 \cdot 3 \\
4 \cdot 1 \\
4 \cdot 1 \\
4 \cdot 2 \\
3 \cdot 8 \\
4 \cdot 1\end{array}$ & $\begin{array}{l}1 \cdot 6 \\
2 \cdot 1 \\
2 \cdot 2 \\
2 \cdot 2 \\
1 \cdot 9 \\
2 \cdot 2\end{array}$ \\
\hline Total & 61 & 61 & 62 & 61 & 245 & & & \\
\hline
\end{tabular}

TABLE 2

AVERAGE NUMBER OF ABSENCES AND AVERAGE SHIFTS LOST PER 100 MEN PER YEAR, DURING 1952, FOR EACH CATEGORY OF ABSENCE

\begin{tabular}{|c|c|c|c|c|c|c|c|c|c|c|}
\hline \multirow{2}{*}{$\begin{array}{l}\text { Hourly Rate } \\
\text { (shillings) }\end{array}$} & \multicolumn{2}{|c|}{$\begin{array}{l}\text { Certificated and } \\
\text { Uncertificated } \\
\text { Sickness }\end{array}$} & \multicolumn{2}{|c|}{$\begin{array}{l}\text { Without } \\
\text { Permission }\end{array}$} & \multicolumn{2}{|c|}{$\begin{array}{c}\text { With } \\
\text { Permission }\end{array}$} & \multicolumn{2}{|c|}{ Injury } & \multicolumn{2}{|c|}{ Total } \\
\hline & $\begin{array}{c}\text { No. } \\
\text { Absences }\end{array}$ & $\begin{array}{l}\text { Shifts } \\
\text { Lost }\end{array}$ & $\begin{array}{c}\text { No. } \\
\text { Absences }\end{array}$ & $\begin{array}{l}\text { Shifts } \\
\text { Lost }\end{array}$ & $\begin{array}{c}\text { No. } \\
\text { Absences }\end{array}$ & $\begin{array}{l}\text { Shifts } \\
\text { Lost }\end{array}$ & $\begin{array}{c}\text { No. } \\
\text { Absences }\end{array}$ & $\begin{array}{l}\text { Shifts } \\
\text { Lost }\end{array}$ & $\begin{array}{c}\text { No. } \\
\text { Absences }\end{array}$ & $\begin{array}{c}\text { Shifts } \\
\text { Lost }\end{array}$ \\
\hline $\begin{array}{l}3 \cdot 4-4 \cdot 09 \\
4 \cdot 1-4 \cdot 29 \\
4 \cdot 3-4 \cdot 49 \\
4 \cdot 5-4 \cdot 89 \\
4 \cdot 9-5 \cdot 99 \\
6 \cdot 0 \text { and over }\end{array}$ & $\begin{array}{l}14 \\
13 \\
27 \\
34 \\
43 \\
53\end{array}$ & $\begin{array}{l}206 \\
169 \\
333 \\
487 \\
810 \\
969\end{array}$ & $\begin{array}{l}340 \\
216 \\
231 \\
305 \\
358 \\
331\end{array}$ & $\begin{array}{l}488 \\
260 \\
325 \\
366 \\
428 \\
363\end{array}$ & $\begin{array}{l}46 \\
35 \\
46 \\
29 \\
25 \\
47\end{array}$ & $\begin{array}{r}257 \\
98 \\
92 \\
76 \\
55 \\
150\end{array}$ & $\begin{array}{l}5 \cdot 3 \\
3 \cdot 5\end{array}$ & $\begin{array}{r}109 \\
94\end{array}$ & $\begin{array}{l}403 \\
271 \\
310 \\
374 \\
425 \\
436\end{array}$ & $\begin{array}{r}1,117 \\
602 \\
850 \\
1,087 \\
1,293 \\
1,614\end{array}$ \\
\hline
\end{tabular}


Thus the increase in total shifts lost at higher wage levels is due chiefly to the increase in recorded sickness absence while the greater total number of absences is the result mainly of more absences without permission.

The association between wage level and sickness absence is very marked; its explanation, however, raises a number of problems. For example, does the association indicate that there is more illness among men at higher wage levels ? To assist the discussion of this problem it was decided to tabulate the medical category for each sickness absence, to calculate the absence for the previous year, 1951, and to examine the number of absences of different lengths in each wage group, taking all absences into account.

In January, 1951, there was a widespread influenza epidemic. If equal exposure to infection is assumed it is of interest to compare the incidence of influenza at higher and lower wage levels. All but 14 of the men had been employed on the same occupation throughout 1951. Thus the wage groups were reasonably comparable during that period. On average there were seven cases of influenza per 100 men in 1951 and less than 1 per 100 in 1952. Of the 1951 cases, $75 \%$ were in the three lower wage groups with the lowest paid group having most of all. Also the average length of absence was slightly greater in these groups. While it is not known how much reliance can be placed upon the diagnoses, these figures suggest that men in the lower pay groups were more susceptible to infection.

The number of absences was mostly too small to allow any analysis by separate medical categories but on examination there was nothing to suggest that the number of more serious illnesses was greater in the upper wage groups. In 1951 the association between sickness absence and wage level was present but was less marked than in 1952. For the two-year period as a whole the time lost through sickness absence was about three times greater in the highest as compared with the lowest paid group.

Further evidence is obtained by taking all absence and examining the number and relative frequency of absences of different duration or length. In most cases it is difficult to obtain the true reason for an absence, or indeed any reason from the absence record, but the length of an absence provides some guide as to its cause, at least in general terms. For instance, of all single shift absences, $90 \%$ were "without permission". (This kind of absence accounted for over $70 \%$ of all absences.) The remaining $10 \%$ were mostly " with permission". For absences of over three shifts' duration, $60 \%$ were recorded as due to sickness or injury, $21 \%$ as with permission, and only $19 \%$ as without permission. Taking absences of over seven shifts in length, $90 \%$ were recorded as due to sickness or injury. This suggests that as the length of an absence increases beyond one shift there is a sharply increasing probability that the reason for it is either sickness (or injury) or one that would be accepted by management.

Table 3 shows the average number and percentage of all absences of given lengths for the wage groups and also, for comparison, the number recorded as due to sickness. For clarity the remaining wage groups have been reduced to two, but in view of its higher absence the figures for the lowest paid group are shown separately.

TABLE 3

(a) AVERAGE NUMBER OF ABSENCES OF EACH LENGTH PER 100 MEN IN 1952 AND (b) THEIR PROPORTION OF THE
TOTAL NUMBER OF ABSENCES IN THE WAGE GROUP

\begin{tabular}{|c|c|c|c|c|c|c|c|c|}
\hline \multirow{2}{*}{$\begin{array}{c}\text { Hourly } \\
\text { Rate } \\
\text { (shillings) }\end{array}$} & \multicolumn{6}{|c|}{ Length of Absence in Shifts } & \multirow[b]{2}{*}{ Total } & \multirow[b]{2}{*}{$\begin{array}{l}\text { Sickness } \\
\text { Absences }\end{array}$} \\
\hline & 1 & 2 & 3 & $4-9$ & $10-19$ & $\begin{array}{c}20 \\
\text { and } \\
\text { Over }\end{array}$ & & \\
\hline $\begin{array}{l}\text { a) } A v \\
3.4 \\
4.1-1 \\
4.5\end{array}$ & $\begin{array}{c}\text { ber of } \\
266 \\
218 \\
320\end{array}$ & $\begin{array}{c}a b s e n \\
63 \\
25 \\
22\end{array}$ & $\begin{array}{c}\text { cesp } \\
3 \\
7 \\
17\end{array}$ & \begin{tabular}{|l}
57 \\
29 \\
21
\end{tabular} & $\begin{array}{c}\operatorname{men} p \\
8 \\
5 \\
17\end{array}$ & $\begin{array}{c}\text { year } \\
6 \\
6 \\
14\end{array}$ & $\begin{array}{l}403 \\
290 \\
411\end{array}$ & $\begin{array}{l}14 \\
20 \\
43\end{array}$ \\
\hline (b) $\begin{array}{r}\text { Table o } \\
3.4-4 \cdot 0 \\
4 \cdot 1-4 \cdot 4 \\
4.5 \text { and } 0\end{array}$ & $\begin{array}{l}66 \\
75 \\
77\end{array}$ & $\mid \begin{array}{r}15.6 \\
8.6 \\
5.4\end{array}$ & $\begin{array}{l}0.8 \\
2.4 \\
4 \cdot 1\end{array}$ & $\mid \begin{array}{r}14.1 \\
10.0 \\
5.1\end{array}$ & \begin{tabular}{|l}
2.0 \\
1.7 \\
$4 \cdot 1$
\end{tabular} & $\begin{array}{l}1.5 \\
2.1 \\
3.4\end{array}$ & $\begin{array}{l}100 \\
100 \\
100\end{array}$ & $\begin{array}{r}3.5 \\
6.9 \\
10.5\end{array}$ \\
\hline
\end{tabular}

The table includes all absence, also the average number of absences per 100 men recorded as due to sickness for the same period.

The main differences between the middle and upper wage levels are (i) the number of single shift absences, (ii) the number of long absences (10 shifts and over), and (iii) the distribution by length of absences of two to nine shifts' duration, although the total number is approximately the same.

Although the number of wage levels is reduced in the table, further analysis showed that, apart from the lowest paid group, the number of single shift absences increased steadily as wage level increased.

A comparison of the distribution of lengths of absences in the middle and upper wage groups shows that the two distributions are quite different. In Table 3(b) the proportion of all absences of over one shift is much the same at both wage levels, i.e. 25 and $22 \%$, but while the proportion of two and four to nine shift absences is greater in the lower paid groups there is a greater proportion of three and over nine shift absences in the upper wage groups. These trends are sustained in the lowest paid group. To some extent the changes in trend and distribution appear to be due to the National Insurance regula- 
tions regarding sickness benefit*, but they also suggest that men at higher wage levels tend to take a longer absence for any given illness.

The number of sickness absences in the upper wage groups is twice as great as in the middle, and three times greater than in the lower wage group. These differences are partly associated with the number of long absences but not with corresponding differences in the number of absences of medium length, although many absences in this range are usually due to illness. To clarify the results all absences were tabulated by length and within each length by category, for the three wage groups. Nearly all absences of over nine shifts' duration were recorded as due to sickness or injury and the remainder as with permission. For absences of one to three shifts there was much more absence without permission at higher wage levels and less sickness absence and absence with permission. The most striking differences, however, were found in the absences of four to nine shifts. The figures are shown in Table 4.

TABLE 4

THE AVERAGE NUMBER AND PROPORTION OF FOUR TO NINE SHIFT ABSENCES IN EACH CATEGORY

\begin{tabular}{|c|c|c|c|c|c|}
\hline $\begin{array}{c}\text { Hourly } \\
\text { Rate } \\
\text { (shillings) }\end{array}$ & & $\begin{array}{c}\text { Sickness } \\
\text { and } \\
\text { Injury }\end{array}$ & $\begin{array}{c}\text { With } \\
\text { Permission }\end{array}$ & $\begin{array}{c}\text { Without } \\
\text { Permission }\end{array}$ & Total \\
\hline 3.4-4.09 & $\begin{array}{c}\text { No. } \\
\text { Absences } \\
\% \\
\text { No. }\end{array}$ & $\begin{array}{c}9 \\
(16)\end{array}$ & $\begin{array}{l}31 \\
(54)\end{array}$ & $\begin{array}{l}17 \\
(30)\end{array}$ & $\begin{array}{c}57 \\
(100)\end{array}$ \\
\hline $4 \cdot 1-4 \cdot 49$ & $\begin{array}{c}\text { Absences } \\
\% \\
\text { No. }\end{array}$ & $\begin{array}{c}7 \\
(24)\end{array}$ & $\begin{array}{c}11 \\
(38)\end{array}$ & $\begin{array}{c}11 \\
(38)\end{array}$ & $\begin{array}{c}29 \\
(100)\end{array}$ \\
\hline $\begin{array}{l}4.5 \text { and } \\
\text { over }\end{array}$ & $\begin{array}{c}\text { Absences } \\
\%\end{array}$ & $\begin{array}{l}14 \\
\text { (67) }\end{array}$ & $\begin{array}{c}5 \\
(24)\end{array}$ & $\begin{array}{l}2 \\
(9)\end{array}$ & $\begin{array}{c}21 \\
(100)\end{array}$ \\
\hline
\end{tabular}

The number of absences of four to nine shifts decreases with increasing wage level from 57 to 21 but the proportion recorded as due to sickness increases from $16 \%$ to $67 \%$. Thus for absences of similar length men at higher wage levels brought sickness certificates to work more often than those at lower pay levels, although it is difficult to see why this should be so. It may be noted that most absences of four to nine shifts were recorded either as sickness or with permission and that while the absence in one category increased, that in the other

*"، Benefit is payable only for days of incapacity which are part of a period of interruption of employment. Any two or more days of incapacity which occur within a period of six consecutive days, excluding Sundays, form a period of interruption of employment. Any two such periods of two or more days each, which are not separated by more than 13 weeks, are treated for benefit purposes as forming a single period of interruption of employment. Benefit is not payable for an isolated day of incapacity which does not form part of a period of interruption of employment. Sickness benefit cannot be paid for the first three days of a period of interruption of employment unless and until there have been at least 12 days of interruption of employment within the 13 weeks beginning on the first waiting day."

(Ministry of Pensions and National Insurance, Leaflet N.I.16.) decreased with wage level. Since the tendency to report illness, bring certificates, or seek permission for absence appears to vary with wage level, these results suggest that in some cases it may be more instructive to analyse the total absence in terms of the length rather than the category of each absence, and that comparisons of sickness absence figures alone may prove misleading.

The relatively higher absence of the lowest paid group is of some interest although the reasons for it are unknown. Later it will be shown that this group works more overtime than any other and there may be some connexion between this and the greater number of single shift absences. Tables 2,3 , and 4 show that this group has many more two-shift absences without permission and absences of four to nine shifts both with, and without permission, and it is these absences which chiefly account for the greater total shifts lost. In view of the tendency of the lower paid men not to report illness or bring certificates, it seems probable that these absences were mainly due to illness.

To summarize, men at higher wage levels lost more time through absence both in terms of shifts lost and number of absences. The greater shifts lost were mainly due to more long absences (10 shifts and over) in the sickness category while the greater number of absences was the result of more singleshift absence without permission. For absences of intermediate length (two to nine shifts) there was no increase with wage level, although their distribution by length varied, and the proportion of absences of four to nine shifts recorded as due to sickness was greater in the higher wage groups. On the question of whether men at higher wage levels experienced more illness, the available evidence was as follows: they did not have a greater number of more serious illnesses than those in lower pay groups; during an influenza epidemic they appeared least affected; they went absent more readily and appeared to take longer absences; lastly, they tended to report and bring evidence of illness more often. Further comment is left for the discussion.

Absence and Family Responsibilities.-Reliable information about marital status and number and age of children is difficult to obtain. In this study note was made of marital status from the firm's persornel card, and also of the man's income tax code number for the tax year 1952-53. The code number provides a reasonable index of marital status and number of dependants if the following assumptions can be made.* (i) That the code number

\footnotetext{
* The code number is only affected by children who are financially dependent on the parent; the family, however, may include other children now at work. A wife's earnings do not normaily affect the husband's code number.
} 
has not been "adjusted" in order to compensate for over or under deduction in the previous year. Errors of this kind should be randomly distributed over the population. (ii) That the man has no appreciable taxable private income or special allowances other than those for a wife and dependent children. This should be true for the majority. (iii) That the man's circumstances do not change throughout the period. This assumption clearly cannot be made for all men although it may be true for a considerable proportion of them providing the period is not greater than a year. Owing to the information available the groups used in this analysis are subject to any errors involved in making these assumptions. Table 5 shows the code number groups, the number of men, and their average age.

TABLE 5

INCOME TAX CODE NUMBER GROUPS, NUMBER OF MEN, AND THEIR AVERAGE AGE

\begin{tabular}{|c|c|c|c|}
\hline $\begin{array}{l}\text { Income Tax } \\
\text { Code } \\
\text { Number }\end{array}$ & Probable Family Responsibilities & $\begin{array}{l}\text { No. } \\
\text { of } \\
\text { Men }\end{array}$ & $\begin{array}{c}\text { Average } \\
\text { Age }\end{array}$ \\
\hline $\begin{array}{l}0-49 \\
50-89 \\
90-109\end{array}$ & $\begin{array}{l}\text { No dependants "Single" } \\
\text { One dependant " Married" } \\
\text { Two dependant3 } \\
\text { " Married, 1 dependent child " }\end{array}$ & $\begin{array}{l}22 \\
61 \\
61\end{array}$ & $\begin{array}{l}37 \\
45 \\
43\end{array}$ \\
\hline $110-124$ & $\begin{array}{l}\text { Three dependants } \\
\text { "Married, } 2 \text { dependent children" }\end{array}$ & 62 & 39 \\
\hline Over 124 & $\begin{array}{l}\text { Four or more dependants } \\
\text { "Married, } 3 \text { or more dependent } \\
\text { children" }\end{array}$ & 61 & 41 \\
\hline
\end{tabular}

Apart from the single men those included here are the same as those in the previous section. Individual code numbers were not available for the 1951-52 tax year. The code number intervals were defined after reference both to the marriage and children's allowances deductable in the tax year 1952-53 and to the distribution of code numbers for several hundred men. The code number intervals are sufficiently broad to allow for most of the variation in code number due to possible adjustments and allowances mentioned under (i) and (ii) above.

Groups of men at the same wage level within a works tend to have the same range of jobs and the conditions of work, and many other factors associated with any one occupation tend therefore to be equated between code number groups at the same pay level. As would be expected, however, there are differences in age distribution between the code number groups. There were few single men and the majority were comparatively young but some were in the very high age groups. Married men with no children also showed a bimodal age distribution, probably corresponding with those who were recently married, and those whose children were no longer financially dependent upon them. In this analysis no distinction between these two was made. In the higher code number groups the age distributions were restricted in range, unimodal, and had approximately the same means.

Table 6 shows the total absence figures of men with different numbers of dependants. The figures are shown for groups at different wage levels which, for greater reliability, have been reduced to two.

TABLE 6

AVERAGE NUMBER OF ABSENCES AND THE AVERAGE AVERAGE NUMBER OF ABSENCES AND THE AVERAGE SHIFTS LOST PER 100 MEN DURING 1952 FOR MEN WITH
DIFFERENT NUMBERS OF DEPENDANTS AND AT

\begin{tabular}{|c|c|c|c|c|c|c|}
\hline \multirow{3}{*}{$\begin{array}{c}\text { Hourly } \\
\text { Rate } \\
\text { (shillings) }\end{array}$} & & \multicolumn{5}{|c|}{ Income Tax Code Number } \\
\hline & & $0-49$ & $50-89$ & $90-109$ & $110-124$ & $\begin{array}{c}\text { Over } \\
124\end{array}$ \\
\hline & & $\begin{array}{c}\text { No } \\
\text { Depen- } \\
\text { dants }\end{array}$ & $\begin{array}{c}\text { One } \\
\text { Depen- } \\
\text { dant }\end{array}$ & $\begin{array}{c}\text { Two } \\
\text { Depen- } \\
\text { dants }\end{array}$ & $\begin{array}{c}\text { Three } \\
\text { Depen- } \\
\text { dants }\end{array}$ & $\begin{array}{l}\text { Four } \\
\text { or } \\
\text { More }\end{array}$ \\
\hline $\begin{array}{l}+4.49 \\
5-6 \cdot 0 \\
\text { id over } \\
\text { btal }\end{array}$ & $\begin{array}{l}\text { No. absences } \\
\text { Shifts lost } \\
\text { No. absences } \\
\text { Shifts lost } \\
\text { No. absences } \\
\text { Shifts lost }\end{array}$ & $\begin{array}{r}564 \\
1,250 \\
= \\
=\end{array}$ & \begin{tabular}{|r|}
348 \\
985 \\
486 \\
1,660 \\
412 \\
1,296
\end{tabular} & $\begin{array}{r}278 \\
500 \\
310 \\
1,090 \\
292 \\
780\end{array}$ & $\begin{array}{r}288 \\
582 \\
400 \\
1,340 \\
339 \\
938\end{array}$ & $\begin{array}{r}367 \\
1,320 \\
457 \\
1,210 \\
408 \\
1,267\end{array}$ \\
\hline
\end{tabular}

The relationship between absence and family responsibilities is $U$ shaped. Absence is high for single men, falls to a minimum for men with two dependants, and then rises again. This is true for both pay groups although the level of absence differs. In general, it will be noted that the increase in absence at higher wage levels is present in all code number groups.

The higher absence of men with three or more dependants is of some interest, and the total absence was analysed first by the category and secondly by the duration or length of each absence. Table 7 shows the absence without permission and the sickness absence for the code number groups. Absence with permission has been omitted but it showed much the same relationship with family responsibilities, except that men with no dependants had very little absence in this category. Injuries appeared to follow the same U-shaped relationship, but their number was too small to allow any conclusion to be drawn.

It will be seen that in the case of absence without permission the U-shaped pattern of absence with family responsibilities is consistent at both pay levels. Also, as shown in the previous section, absence is greater at the higher pay level.

Sickness absence also follows the same $U$-shaped pattern in the lower pay group but is not quite as regular in the higher one. When the number of men having one or more sickness absences in the year was examined, however, the relationship was found in both pay groups. 
TABLE 7

AVERAGE NUMBER OF ABSENCES AND SHIFTS LOST PER 100 MEN DURING 1952 IN SICKNESS AND WITHOUT PER MISSION FOR MEN WITH DIFFERENT NUMBERS OF DEPENDANTS AND AT DIFFERENT WAGE LEVELS

\begin{tabular}{|c|c|c|c|c|c|c|c|c|c|c|c|}
\hline \multirow{3}{*}{$\begin{array}{c}\text { Hourly Rate } \\
\text { (shillings) }\end{array}$} & & \multicolumn{5}{|c|}{ Sickness Absence } & \multicolumn{5}{|c|}{ Absence without Permission } \\
\hline & & \multicolumn{10}{|c|}{ Number of Dependants } \\
\hline & & None & One & Two & Three & $\begin{array}{l}\text { Four or } \\
\text { More }\end{array}$ & None & One & Two & Three & $\begin{array}{c}\text { Four or } \\
\text { More }\end{array}$ \\
\hline $\begin{array}{l}3.4-4.49 \\
4.5-6.0 \text { and over } \\
\text { Total }\end{array}$ & $\begin{array}{l}\text { No. absences } \\
\text { Shifts lost } \\
\text { No. absences } \\
\text { Shifts lost } \\
\text { No. absences } \\
\text { Shifts lost }\end{array}$ & $\begin{array}{l}36 \\
495 \\
= \\
= \\
=\end{array}$ & $\begin{array}{r}24 \\
458 \\
61 \\
761 \\
41 \\
596\end{array}$ & $\begin{array}{r}13 \\
69 \\
17 \\
717 \\
15 \\
377\end{array}$ & $\begin{array}{r}15 \\
155 \\
56 \\
834 \\
34 \\
472\end{array}$ & $\begin{array}{r}21 \\
339 \\
39 \\
696 \\
30 \\
495\end{array}$ & $\begin{array}{l}490 \\
673 \\
- \\
= \\
-\end{array}$ & $\begin{array}{l}267 \\
373 \\
364 \\
446 \\
311 \\
406\end{array}$ & $\begin{array}{l}231 \\
297 \\
255 \\
283 \\
242 \\
290\end{array}$ & $\begin{array}{l}239 \\
306 \\
317 \\
379 \\
275 \\
340\end{array}$ & $\begin{array}{l}282 \\
400 \\
393 \\
443 \\
332 \\
419\end{array}$ \\
\hline
\end{tabular}

Table 8 shows the frequency of all absences of different lengths for each code number group for the total sample. Single men have been included but, as they were all at the three lower wage levels, their absence figures are not strictly comparable with other groups.

TABLE 8

AVERAGE NUMBER OF ABSENCES OF EACH LENGTH PER 100 MEN IN 1952

\begin{tabular}{|c|c|c|c|c|c|}
\hline \multirow{3}{*}{$\begin{array}{l}\text { Length of Absence } \\
\text { in Shifts }\end{array}$} & \multicolumn{5}{|c|}{ Income Tax Code Number } \\
\hline & $0-49$ & $50-89$ & $90-109$ & $110-124$ & $\begin{array}{r}\text { Over } \\
124\end{array}$ \\
\hline & $\begin{array}{c}\text { No } \\
\text { Depen- } \\
\text { dants }\end{array}$ & $\begin{array}{c}\text { One } \\
\text { Depen- } \\
\text { dant }\end{array}$ & $\begin{array}{c}\text { Two } \\
\text { Depen- } \\
\text { dants }\end{array}$ & $\begin{array}{c}\text { Three } \\
\text { Depen- } \\
\text { dants }\end{array}$ & $\begin{array}{l}\text { Four } \\
\text { or } \\
\text { More }\end{array}$ \\
\hline $\begin{array}{c}1 \\
2 \\
3 \\
4-9 \\
10-19 \\
20 \text { shifts and over }\end{array}$ & $\begin{array}{r}418 \\
73 \\
14 \\
41 \\
14 \\
4\end{array}$ & $\begin{array}{r}295 \\
38 \\
10 \\
44 \\
12 \\
13\end{array}$ & $\begin{array}{r}223 \\
33 \\
6 \\
20 \\
5 \\
5\end{array}$ & $\begin{array}{r}261 \\
21 \\
11 \\
23 \\
13 \\
10\end{array}$ & $\begin{array}{r}310 \\
24 \\
16 \\
31 \\
15 \\
12\end{array}$ \\
\hline Total .. & 564 & 412 & 292 & 339 & 408 \\
\hline
\end{tabular}

The table includes all absence.

The table shows that the U-shaped relationship is present in both the short absences, which are mainly without permission and in the longer absences which are chiefly due to illness.

The largest differences between groups are found in the number of single, and over-three shift absences, and the question arises whether the latter reflect genuine differences in the incidence and severity of illness. This point will be referred to in the discussion.

To ensure that the U-shaped absence pattern was not due to the age differences between the groups, a 10 -year age group was examined. The men in this restricted age range were grouped by their code number and the groups were matched for wage level. The absence pattern both for shifts lost and number of absences was maintained and is therefore not due to age.*

Wage Level, Family Responsibilities, and Overtime Working.- No cumulative record of actual hours worked or of overtime was kept, only the number of hours paid was recorded. These took into account special shift and overtime allowances. Thus one hour's work paid at time and a half would be recorded as one and a half paid hours. It was possible, however, to estimate $\dagger$ the number of overtime paid hours for each man for a nine-month period and these were calculated for the men in each of the original 24 groups which divided the sample by wage level and family responsibilities. The overtime paid hours cannot be translated into actual hours, but they provide some indication of the relative amounts of overtime worked.

On three-shift systems there are few occasions on which overtime work is possible and it occurred mainly on rest days or, occasionally, when two consecutive shifts were worked. From the records available it was impossible to discover whether opportunity for overtime was similar in different occupations. At any one wage level, however, men are mostly on the same range of jobs and should have equal opportunities for overtime working. It is therefore possible to compare the overtime of men with different numbers of dependants who are at the same wage level. Opportunity may not have been comparable, however, at different wage levels.

The results are shown in Fig. 1. For greater reliability the upper four wage groups have been reduced to two, but as the absence of the lowest

*As discussed above, age and family responsibilities are related, although the relation is complex. In view of the association between number of dependants and absence it is of interest to re-examine the relationship between age and absence, taking family responsibilities into account. This has been done by Dr. B. Petz but the results have not yet been published.

†Estimated overtime paid hours $=$ (actual paid hours) plus (hours lost $\times$ C) minus (planned " paid" hours),

where $\mathrm{C}=$ Planned " paid" hours

Planned hours 
paid group was not consistent with the general trend, the overtime figures are shown separately.

Fig. 1 shows that the relation between family responsibilities and the extent of overtime working depends upon wage level. At lower wage levels there is a considerable increase in overtime working with increasing family responsibilities. In the higher pay groups there is little or no relationship.

The variation in overtime working between different code number groups is as great as that between the wage levels. As wage level increases the extent of overtime working diminishes; this trend is sustained in all code number groups. It seems unlikely that these trends merely reflect differences in opportunity for overtime but the possibility remains.

There are two further points of interest. Although men with over three dependants have more absence they also work more overtime. Similarly, the lowest paid group has the highest overtime figures as well as a higher

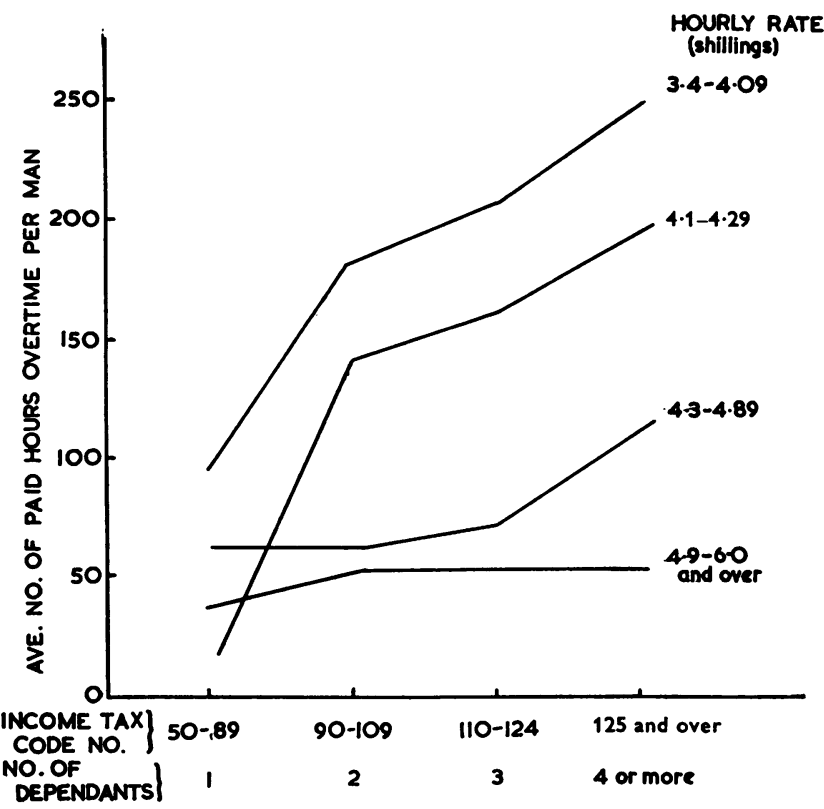

Fig. 1.-The average number of paid hours overtime per man from April to December, 1952, for groups with different numbers of dependants and at different wage levels. absence rate. Thus in these groups a higher absence rate does not necessarily indicate a lower overall attendance rate.

In connexion with these results, two characteristics of income tax are relevant: (i) As taxable income increases the rate at which tax is levied increases by steps up to the standard rate. Thereafter the amount of tax increases as a simple function of income. Thus the value of an extra pound in wages, whether from overtime working or other source, decreases as income level increases. (ii) At a low rate of tax any allowance against taxable income is of less value than at a higher rate. Thus at lower gross income levels men with several dependants derive less benefit from their incometax allowances. Thus for men at the same gross wage level and for the same attendance at work the difference in net income between men with one and four dependants respectively is small at low income levels but increases rapidly as wage level increases. Differences in income of similar magnitude appear to affect overtime working. The changing relation between overtime working and number of dependants as wage level changes may therefore be due partly to characteristics of income tax.

It is of interest to note that the actual difference in net income between those with one and four dependants was almost constant at all wage levels. (The actual differences were from the lowest to the highest wage levels $£ 76, £ 76, £ 61, £ 72, £ 70$, $£ 87$. For the same total attendance the expected differences would be $£ 24, £ 35, £ 38, £ 47, £ 65$ and $£ 82$.) This constancy results mainly from the lower absence and greater overtime working of men with several dependants at lower wage levels.

\section{Discussion}

Before discussing the findings some possible limitations must be considered. The results are based on data from one works and in an industry where there are wide pay differentials which are not always closely related to skill or responsibility. This situation is a favourable one for investigating the relation between wage level and absence but the results may not be applicable to situations where pay and responsibility are closely linked. This qualification should not apply to the results relating to family responsibilities. It should also be remembered that the findings concern men on threeshift work.

At lower pay levels overtime working increased markedly in groups with progressively greater family responsibilities: in the higher pay groups there was little or no relationship. One interpretation of this result is that the higher paid men with dependants, unlike those with a lower income, felt no need to supplement their earnings by working overtime. The result showing that as wage level 
increased the extent of overtime working decreased must be treated with caution since opportunity may not have been comparable. There is no direct evidence that income tax or tax reliefs affected these results but they could partly account for the particular relationships found.

The association between sickness absence and wage level was very marked and the problem arises whether the greater absence reflects an increase in illness at higher wage levels. This raises the general question of the relation between illness and absence from work and between the incidence and severity of illness in a group and the amount of sickness absence. For the range of income under investigation, there appear to be no a priori grounds for suspecting a greater incidence of illness in the higher paid groups but the possibility cannot be ruled out. When comparing sickness absence rates, however, it is necessary to enquire whether any differences are attributable more to differences in the tendency to go absent when ill, report an illness, or bring a certificate on returning to work, than to differences in the amount of illness itself.

Analysis showed that at lower wage levels some absences of medium length which were probably due to illness were either not reported or recorded as such. In these groups there were few absences of three shifts but relatively many absences of four to nine shifts and it might be expected that the men would obtain sickness certificates and avail themselves of National Insurance benefit. Here it may be noted that the regulations are such that it is often necessary to obtain two certificates, or one and a note, if the man is both to claim benefit and bring evidence of illness. If he belongs to a private sick benefit club, a third certificate may be required. There was no paid sick leave scheme in the works and for short-term absence there was no great incentive, financial or otherwise, to bring a certificate. Thus whether one was brought may depend on many other factors beyond the scope of this study.

While no definite conclusion can be drawn it seems likely that the greater recorded sickness absence of the highest paid groups was attributable more to a change in the response to illness than to any differences in the incidence of illness itself. If this is correct the results showing an increase in absence at higher wage levels are best explained in terms of $(a)$ a greater tendency to go absent for any given reason, illness or otherwise, $(b)$ a tendency to stay away longer for any given illness, and (c) differences in the reporting of illness.

If the assumption of equal incidence and severity of illness is correct the question arises whether the greater total shifts lost at higher wage levels were 5* in any sense unnecessary. In this works absence entailed a complete loss of wages and it might be argued that the sickness absences of all men, including the higher paid, were mainly due to their feeling unfit for work. If this was so, it may be asked whether the lower paid men were remaining at, or returning to work when they were unfit to do so. The results suggesting that during the influenza epidemic of 1951 men in the lower wage groups were most affected may have some bearing on this question.

The results of this study also suggest that comparison of sickness or other absence rates may be misleading unless the distribution of wage rates and family responsibilities are fairly similar in the groups compared.

Previous work on the relation between wage level and absence is limited, although many authors mention the importance of pay. In 1928 Vernon and Bedford reported that the absence rate for colliers varied between $17.3 \%$ and $16 \%$ as the mean wage index varied from 163.1 to $147 \cdot 5$. In a later report (1931), the same investigators conclude that " absenteeism is greatly influenced by economic conditions, for when the possible earnings of coalface workers fell by $32 \%$, the time lost by voluntary absenteeism fell to a half, and that lost by sickness fell to three-fourths." Other underground and surface men also showed reductions. These results, however, must be treated with caution. The period covered by the study, 1924-28, was one of great upheaval in the industry and during this time, apart from the long dispute in 1926, the fall in possible earnings was associated with a reduction in the number of possible shifts per week.

Recent investigations (Buzzard and Shaw, 1952) and Denerley (1952) have shown that when a paid sick leave scheme is introduced the time lost through sickness is substantially increased. Although some abuse seems inevitable the writers consider it to be small in extent and suggest two ways in which the scheme may affect sickness absence. First, it " will enable many people to be absent who ought to have been absent before" (Buzzard and Shaw), and, second, it " may help to prevent further sickness by providing the opportunity to recuperate fully before resuming work" (Denerley). Buzzard and Shaw also report a " distinct and striking difference between workers who receive incentive payment and those who do not ". Not only the sickness rate but also the proportional increase after the introduction of the scheme was lower for the incentive worker. They note that this may in part be due to the fact that the incentive worker receives less money when absent sick than when at work. The day wage man on the other hand may actually be a little better off 
when sick if possible overtime earnings are not considered.

These studies show that factors other than the incidence and severity of illness play an important part in determining the amount of sickness absence although the latter must clearly have some limiting effect. The evidence suggests that a man's willingness to go absent when ill, or return to work when on the way to recovery, is to a large extent a function of his financial circumstances before and during the absence.

In the present study the relationship between absence and family responsibilities was found to be $\mathrm{U}$ shaped. Absence was higher for single men, fell to a minimum for those with two dependants, and then increased progressively for men with more than two dependants. The U-shaped relationship between absence and number of dependants was found in all categories of absence including sickness absence. It was also found for absences of all lengths. Thus the extent of a man's family responsibilities affects his total absence behaviour rather than any particular category or length of absence.

Noland (1946) reported that those with the least absence had more dependants but he gave no details or figures. Whitehead (1948), in a study of Australian munition workers made during the war, found that

" of female workers who had children, those with three or more children had the most absences and lost most time through sickness absence. Among male workers those with children, on average, had fewer absences and lost less time than those without children; however, among those with children the rates tended to increase with the number of children, although these variations were not statistically significant."

Comparing wage levels, there was no reason to expect differences in the incidence of illness but in comparing men with different numbers of dependants there are some $a$ priori grounds for suspecting systematic differences in the amount of illness. Men with several dependants may experience a greater degree of stress of various kinds than those with few dependants. There may also be differences in the exposure to infection. It may be noted that men with several dependants had more sickness absence but also worked more overtime. This situation may be contrasted with that of men at higher wage levels who had more sickness absence but who worked less overtime. While great caution is necessary in interpreting differences in sickness absence figures the results are consistent with the view that differences in family responsibilities are associated with differences in the incidence of illness.

The underlying factors which give rise to the association between absence and number of dependants are complex and require further studies, probably of an interview nature. Among the many variables to be considered are differences in (i) financial status and security between groups due, for example, to income tax reliefs, family allowances, etc., or to differences in the number of wage earners per family unit; (ii) the care the individual receives when ill, which may also be determined by family composition, and (iii) the leisure habits and needs of men with differing family responsibilities.

The findings as a whole suggest that an absence from work may be considered as the result of a choice on the part of the individual. On most working days of the year the question of whether to attend or not may never arise. Three-quarters of the men had fewer than five absences a year. Thus the balance is normally weighted heavily in favour of attendance. In the case of many injuries and more serious illnesses absence is of course inevitable, but these, relative to other absence, are rare events. The problem of absence from work may therefore be conceived as that of discovering the main factors which singly or together determine whether and when this "choice" situation will occur and those which determine the outcome. For example, slight indisposition may be thought of as an event which precipitates a "choice" situation, while wage level or a paid sick leave scheme are factors which may partly determine the outcome. Thus two broad groups of causal factors may be distinguished: (a) the more immediate and often highly spacific factors or events which raise the question of whether to go absent or not; and $(b)$ the more long-term and general factors which determine how heavily weighted is the initial balance towards attendance. The latter implies the concept of an individual absence threshold, the level being determined by both personal factors and by the general conditions of work.

The specific events underlying an absence are usually commonplace and correspond most closely to a " reason" for it. However, events or potential " reasons" of one particular kind, or class, may occur more often in some groups than others, e.g., in groups with differing family responsibilities; they may also be associated more with some times of the day, ${ }^{*}$ or days of the week, than with others. One step towards understanding, predicting, and coping with absence lies in discovering such associations. Of the more general factors the problem is to find the most important in determining how strongly the individual will strive to maintain full attendance at work. The evidence in this paper suggests that

*In this connexion the authors found (1956) that on three-shift work, three-quarters of the single-shift absences without permission occurred on the morning (6 a.m. to 2 p.m.) shift, and appeared to be associated with the early start. 
wage level may be one such factor. Family responsibilities may also act in this way but, in addition it seems likely that the question of whether to go absent or not occurs more frequently in some family responsibility groups than in others.

\section{Summary}

Men at different wage levels employed in an iron and steel works were compared with respect to their absence from work and overtime working. The men were also grouped according to their family responsibilities, or number of dependants, as indicated by their income-tax code number. There was no paid sick leave scheme.

The amount of overtime working decreased at higher wage levels. This trend was found in all family responsibility groups. There was a relationship between family responsibilities and overtime working but its nature depended upon the wage level of the men concerned. At lower pay levels overtime working increased markedly in groups with progressively greater family responsibilities; at higher pay levels there was little or no increase.

Men at higher wage levels lost more time through absence, both in terms of shifts lost and number of absences. The increase in total shifts lost was due mainly to more long absences (10 shifts and over) recorded as due to sickness, while the increase in the total number of absences was due chiefly to more single-shift absences recorded as without permission.
For absences of intermediate length (two to nine shifts), there was no increase with wage level, although their distribution by length varied and the proportion recorded as due to sickness was greater in the higher wage groups.

The relationship between absence and family responsibilities was found to be $U$ shaped. Absence was higher for single men, fell to a minimum for those with two dependants, and then increased progressively for men with more than two dependants. This result was independent of wage level and was found in all lengths and categories of absence including sickness absence.

This work has been under the general direction of Mr. J. W. Whitfield, Reader in Psychology, University College, London, and Dr. R. B. Buzzard, to whom we are greatly indebted for help and encouragement. We are also grateful to our colleagues at University College for their valuable criticism. We wish to thank the management for their generous cooperation, and we are especially grateful to the medical officers for their assistance and hospitality.

\section{REFERENCES}

Buzzard, R. B., and Shaw, W. J. (1952). Brit. J. industr. Med., 9, 282 Denerley, R. A.

Noland, E. W. (1946). Factory Management and Maintenance, 104, No. 1,131 .

Shepherd, R. D., and Walker, J. (1956). Occup. Psychol., 30, 105

Shepherd, R. D., and Walker, J. (1956). Occup. Ps.

Vernon, H. M., and Bedford, T. (1928). Rep. industr. Fatigue Res. Bd. (Lond.), No. 51.

Whit (1931). Rep. industr. Hlth Res. Bd. (Lond.), No. 62. Whitehead, M. (1948). Bull. industr. Psychol. Personnel Pract.
4, No. 3, p. 3. 